\title{
Biopower transformation and the challenge of safe agricultural production (socio- philosophical and political-economic aspects)
}

\author{
A.V. Shilovtsev ${ }^{1,2, *}$, K.P. Stozhko ${ }^{2}$, D.K. Stozhko ${ }^{3}$, A.G. Aleksandrov ${ }^{1}$, and JoseLuis Lopez \\ Garcia $^{4}$ \\ ${ }^{1}$ Ural Federal University named after the first President of Russia B. N. Yeltsin, Yekaterinburg, \\ Russia \\ ${ }^{2}$ Ural State Agrarian University, Yekaterinburg, Russia \\ ${ }^{3}$ Ural State University of Economics, Yekaterinburg, Russia \\ ${ }^{4}$ Universidad Poltecnica de Madrid, Ramiro de Maeztu, 7, 28040 Madrid, Spain
}

\begin{abstract}
. paper analyzes the character of modern biopower from the socio-philosophical and political-economic viewpoints in the scope of the society's transition to a new technological wave and the necessity of ensuring the secure existence of people. Using argicultural production as an example, the main trends and peculiarities of such transformation, the issues arising in this regard, and the ways to solve them are shown. Their impact on the existential crisis of personality developing in the modern "risk society" is also significant. The authors try to identify the prospects for the development of biopower and modern biopolitics in the scope of the new social reality, growing macroeconomic uncertainty, and risks.
\end{abstract}

\section{Introduction}

Due to the anthropogenic and epidemiological conditions that have developed in the world over the past year, modern science and society are faced with the problem of developing fundamentally new solutions for the preservation of human life. Forty years ago, science has confirmed the considerable impact of microorganisms on the development and evolution of biogeocenoses [1]. The last decades and the pandemics of Ebola, avian influenza, and the Covid-19 virus have only proved the urgency of this situation. In the twenty-first century, we are not just talking about microbiology, but about engineering virology and artificial intervention in the genome. Meaningful development of the institutions of modern biopower and elaboration of a certain strategy of state policy (biopolitics) aimed at minimizing the risks and threats to the secure existence of a person are necessitated in such a situation.

The urgency of the issue is due to the emergence in modern conditions of a relatively new social and biopolitical destruction in the form of bioaparteid. A prime example is the

\footnotetext{
* Corresponding author: a.shilovtsev@mail.ru
} 
case of vaccination against Covid-19, when the US and the EU actively oppose the use of the Russian Sputnik-V vaccine, trying to enforce considerably less effective vaccines from AstraZeneca and Pfizer on the population. This example indicates how the state authority becomes a biopower, mediating the life and death of millions of citizens. As bioapartheid may rapidly become the norm at the global level, a serious analysis of its causes, potential consequences, and ways to prevent and spread it is required.

Currently, there are two main versions of biopower in science. According to $\mathrm{M}$. Foucault, biopower means the right of the state to manage the lives of its subjects at its own judgment [2]. J. Agambena argues that the state gives primacy to the law, which it is required to follow strictly and the main meaning of the laws is the preservation of people's lives [3].

However, there are two fundamental challenges to be addressed here. The first one is that biopower as a particular technology of the state is formed by the so-called "disciplinary organizations" (M. Foucault's term). These usually include organizations and institutions of the health care system and social insurance. Nevertheless, pharmaceutical corporations (Pfizer, Roche, Novartis, Jonson \& Jonson, Merc \& Co, AddVie, Amgen, etc.) play an integral role in the development of biopower technology.

The second challenge is connected with the type of local laws and the compliance or non-compliance of legal norms with the principles of social justice and social security. It is getting more and more obvious that modern legislation and law enforcement practice do not match the challenges of the time. These items together lead to the emergence of such a phenomenon as "biopolitical state racism" (M. Foucault's term).

Therefore, two main models of state functioning mediate the process of development and reformation of biopower in the modern world: from "covid-denial" (J. Agamben) to the propaganda of the "states-prisons" pattern with its prohibitions, restrictions, and structural violence (M. Foucault).

Many authors take up the issues of biopower, biogeocenoses, biopolitics, and bioethics: K. Yu. Alasania, A.V. Babaeva, F. B. Zagyrtdinova, A. I. Zhelnin, V. Yu. Lebedev, A. S. Makarychev, S. V. Pustovit, A. S. Sozinov, I. D. Somin, P. D. Tishchenko, A.V. Fedorov, B. G. Yudin, A.V. Yarkeeva, and others.

Foreign researches also deal with this topic, namely, H. Arendt, A. Badiou, W. Dekker, J. Deleuze, S. Zizek, G. Jonas, A. Negri, W. Potter, J. Rendtorf, F. Rogers, D. Sokol, M. Hardt, R. Esposito, and others.

The purpose of the research is to give a socio-philosophical and political-economic evaluation of the modern transformation processes of biopower, biopolitics and biogeocenoses in the scope of ensuring a secure human existence.

The objectives of the research are: analysis of the current legal framework and law enforcement practice in providing a secure existence of the population; evaluation of modern technical and technological innovations in the transformation of biopower; determination of the peculiarities of modern agricultural policy in the conditions of ecological and anthropogenic crisis; development of guidelines for the organization of biopolitics and the design of a model of a secure human existence.

\section{Materials and methods}

The following sources are used in this paper:

- statistical and reporting data of the Ministry of Agriculture of the Russian Federation, the Ministry of Economic Development of the Russian Federation, the Ministry of Labor and Social Protection of the Russian Federation, Rosstat for the period from 2012 to 2020; 
- academic articles and monographs published on this issue in the public media;

- proceedings of a number of international and Russian scientific conferences;

- official materials of the International Labour Organization (ILO); legislative and legal documents of the Russian Federation.

On the basis of program-oriented and structural-functional techniques, as well as methods of grouping statistical data of economic hermeneutics, an expert evaluation of the challenge of biopower transformation in the existing biogeocenoses and the supply of an algorithm for the secure existence of a person in the scope of the current man-made and ecological situation is performed.

\section{Results}

In accordance with the Constitution of the Russian Federation, the source of state power and sovereignty in our country is its multi-ethnic people. It is formed by the population of different regions and territories, which is united not only by the common language, culture and economic system, but, first of all, by the conditions of anthropological security shared among them. During the emergency situation (and this is the current situation), it was revealed that the real, and not the imaginary, "the sovereign is the one who decides on the state of emergency". [4, p.15].

The modern anthropogenic situation that has developed in the world over the past two decades shows that the quality of life of people is steadily worsening. The degradation of natural and climatic conditions ( global climate warming, anthropogenic impacts, etc.), pollution (alkalization, bogging, etc.) of the soil, degradation of water sources (from rivers and lakes to seas and oceans), forest burning (from the Amazon to the Siberian taiga), and finally, the decline in the quality of the atmosphere (reduction of the ozone layer, increase in the content of $\mathrm{CO} 2$ and the mass of other hazardous substances in the air) is a reality that humanity has to live with.

It concerns not only the poor, but also the industrially developed countries. Thus, in the Black Sea (according to satellite data), more than 450 garbage islands (with an average size of 2-3 square kilometers) were identified. The Don, Dnieper, Danube, and Southern Bug rivers transport industrial waste to the sea. There is still no appropriate convention regulating the ecological state of the Black Sea.

However, the largest garbage island of several thousand square kilometers is situated in the northern waters of the Pacific Ocean. Today, according to the World Ocean Atlas, only $4 \%$ of the ocean's surface is not polluted. The most polluted are the North, South Korea, East China, Caribbean, Mediterranean, Red and Bering Seas, as well as the Gulf of Mexico. riparian country.

Additionally, to the ecological challenge, the phenomenon of biopower is also related to the agricultural challenge. The exponential growth of the world's population has caused an unprecedented demand for agricultural products. First of all, for food. Now there is a limitation of supplies to the world markets of rice from Asian countries, grain from Russia, Canada, and other expressions of the recession, to which the agricultural economy is pushed by COVID-19. And here the society faces new risks and challenges.

The first of them is the lack of available agricultural land, which is already fully distributed among large private owners. The total volume of the country's land fund is 1709.8 million hectares, while agricultural land accounts for only 400 million hectares [5].

The limitation of areas suitable for agricultural activity and the steady deterioration of their quality (pollution, erosion, etc.) result in a decrease in agricultural productivity. Consequently, the decline in the quality of life is most obvious in the steady increase in the 
prices of food and medicines, in the reduction of their quality (associated with the use of GMOs and other modern technologies to reduce the cost of production).

In China, for example, pork prices almost doubled in 2019, despite the fact that China consumes 55 million tons of this meat annually, i.e., the same amount as the rest of the world combined. In the world markets, grain prices are also rising, according to the data of the "Center for Agroanalytics". It should not deceive anyone that under these conditions, new prospects for the export of agricultural products are opening up for the Russian Federation: the country's food security is at risk when it accumulates. As in the well-known popular saying, "cobbler" may not wear "shoes", first of all, because in our country there is no strategic (designed for decades) reserve (stock) of food required to ensure food security.

At present, the Ministry of Agriculture of the Russian Federation is working to create at least a two-month strategic food reserve in the country. This was prompted by the coronavirus pandemic and associated factors: a drop in food production in a number of countries, a decline in logistics, etc. Thus, the development of a food storage unit in the Russian Federation is the most significant strategic task.

Without a doubt, what the Ministry of Agriculture of the Russian Federation offers is not the Kuban Genetic Seed Bank or the famous collection of N. I. Vavilov, and, furthermore, not the Svalbard Global Seed Vault.

The issue of developing such a strategic Russian food storage facility is still at the project stage. There is a search for territories suitable for long-term food storage. Traditionally, such places are sought in the permafrost zone, for example, on Taimyr. However, the well-known environmental disaster that occurred on July 12, 2020, related to the activities of Nornickeltransgaz AO (part of Nornickel MMC), probably forever excluded the peninsula as the site of the Russian food storage facility. As a result of the accident, about 21 tons of oil products fall into the Ambarnaya, Daldykan and Bolshaya Kheta rivers. This disaster was the second largest in the history of Russia after the 94-ton oil spill in the Komi Republic in 1994. The Office of the Federal Service for Surveillance of Consumer Rights Protection and Human Wellbeing estimated the environmental damage from the oil spill in Norilsk at 148 billion rubles.

Regrettably, the hopes for the rapid development of creonics for long-term storage of food products are hardly worth considering, since all this is expensive and difficult. Freezing does not kill microbes (bacteria, yeast and mold), which means that there is still a risk of food poisoning with such products (listeriosis, mycotoxicosis, salmonellosis, botulism, etc.). However, since the standards for storing bioproducts have long been known [6], time requires urgent activities.

In the scope of growing macroeconomic uncertainty and risks, the question arises concerning the close connection between agricultural and environmental policies, as well as their intermediation by the norms of bioethics. The new social reality demands a substantial adjustment of traditional bioethics and, for example, medical bioethics, environmental bioethics, and global bioethics. New technologies (automation, computerization, and digitalization) are fundamentally transforming the ability to think and the forms of interpersonal dealings. Therefore, the established biogeocenoses have to be conceived by modern man in a slightly different way than two or three decades ago. Nowadays, there are no wild landscapes and ecosystems left on the planet. All of them, in varying degrees, are the result of man - made human activity. Resort areas, urbanizations, and natural parks have substituted "habitat" formats for the natural environment surrounding humans. Issues of payment for the use of these new "formats" replace the once free consumption.

The very same applies to agricultural production and agricultural policy. Is it ethical to ask the public to pay for organic food or to produce genetically modified products, knowing about their health risks? The question is no longer even from the sphere of bioethics, but 
from the field of nooethics. It is the ethics of the modern noosphere in which a person lives and the answers to them have yet to be granted to science.

A comparative analysis of different models of agricultural policy of modern states enables us to reveal completely heterogeneous vectors of its development. It ranges from the resource-saving model related to the spread of the resource-saving regime and their deep (waste-free) processing and use, to the alarmist model, which is of gradual abandonment of the use of natural resources and the switch to the artificial production of the necessary factors of production. There are also countries that still implement expansionist and extensive agricultural policies, turning itself (or others) into the raw materials attachments of modern industrialized powers. Principally, the presence of different models of agricultural policy reflects the transition of certain countries to different models of production. In some cases, there is a shift from the "cost-based production" model to the "lean production" model; in other cases: from the "fast-responding production" model to the "active production" model, and so on.

The multidirectional character of the development of agricultural policy models of modern states objectively requires the development of a common strategy in the field of bioethics and biopolitics to maintain and improve existing biogeocenoses. Here, the sociophilosophical and political-economic understanding of the issue enables us to pose and solve the problems of improving international and Russian legislation that meets the challenges of the time. Particularly, it is essential to speed up the adoption of the "Environmental Code of the Russian Federation", which has been under discussion for a decade.

The assertions that the existing regulatory and legislative framework is quite sufficient for effective biopolitics are untenable. Firstly, many of the laws and regulations are quickly becoming outdated in today's reality. Secondly, many of the requirements of regulatory legal acts are simply not fulfilled, and the sanctions for their violation are inadequate to reality.

For example, in the Russian Federation, there is a sufficiently solid legal framework for the implementation of an effective agricultural policy. Yet it is not capable of ensuring the efficient distribution of natural (land) rent among all participants in agricultural production [7].

Speaking about arbitrary deforestation in the country, smuggling in the field of fishing or hunting, a large number of questions have been built up here as well. However, the main thing is that the adoption of the "Environmental Code" in the Russian Federation will enable the systematic implementation of the fundamental principles of bioethics: the principle of "contaminant pays", the principle of secure existence, the principle of polymorphism, etc. Nowadays, although all these principles exist in various legal documents, their enforcement practice is still unefficient.

Consequently, all this indicates that the existing legal basis for an effective agricultural policy is often not come true. The growing negative impact of monopolies on the agricultural, industrial, food and environmental policies of the state, their use of various schemes of accessing budget funds and their functioning in the "gray zone" is unmistakable.

Conventionally, by the nature of agricultural policy, all countries can be divided into three large groups. The first category consists of countries where agronomic and biological limits have already been reached and the main driving force is the growth of labor productivity, its automation and computerization. The second group includes countries where hand labor accounts for about half of all costs, and modernization is both selective and partial. The third group consists of countries with a large share of hand labor and an incredibly small share of its technical and technological equipment. The agrarian economy 
of such countries is connected with the scenario of "catching up development". It is believed that Russia has certain features of an extensive model related specifically to the "catch-up development" scenario [8].

The feature of the agricultural policy of the Russian Federation is its polymorphism. The huge difference in the natural-climatic and socio-economic conditions of various subjects implies that it is unthinkable to stop at the use of any one model of agricultural policy. Therefore, it is advisable to develop a basic model of the impact of specific factors of different subjects of the Russian Federation (such as land cadastres) on the safety of agricultural production and "road maps" for the reorganisation of regional agricultural policy, according to the current reality.

The theoretical and methodological foundation for constructing such a basic model is cognitive modeling, which may be implemented in several stages: problem definition; categorization of the basic factors influencing its solution (using SWOT and PEST analysis); design of a cognitive map and the choice of an algorithm for solving the problem; organization of experimental simulation training; its implementation as a technological and legal rule.

There are also challenges in the financial support of the agricultural policy of the Russian Federation. While in 2019, the volume of financing for agriculture even increased slightly, but in total terms, it remains relatively small. As a percentage, state financing of agriculture in 2019 accounted for $56 \%$ of the total financing of Russian farmers. This also demonstrates the unprofitability and subsidized nature of many agricultural sectors.

The state program for the integrated development of rural areas for the period from 2020 to 2025 provides for the allocation of 2.3 trillion rubles, of which 1 trillion rubles is allocated from the budget [9]. Meanwhile, it is planned to allocate 290.134 billion rubles for the development of the agroindustrial complex in 2020; 292.863 billion rubles in 2021, and 328.883 billion rubles in 2022. At the same time, the volume of budget spending in 2020 should amount to 19.5 trillion rubles. To put it another way, less than $4.67 \%$ of the total budget expenditures for the specified period are allocated from the budget for the development of agriculture in the Russian Federation.

Technological policy is also indissolubly linked with agricultural policy. In particular, when cellular engineering makes way for qualitatively new methods of food production (biotechnology), the question arises about the compliance of such technologies with the quality of human life. It is known that, in contrast to agricultural technologies, biotechnologies do not rely on the weather, the quality of management, or the organization of production. The result of such biotechnologies is often not a safe product. Moreover, hybritization has long won a strong position in the production of specific agricultural products [10].

The modern scientific and technological revolution generates new challenges for people, which involves the search for answers and the development of programs for their effective solution [11]. A major challenge is the security of human existence, which largely relies on the safety of agricultural production and the environment.

\section{Conclusion}

Several points can be proposed as conclusions from this research.

Firstly, there is currently a qualitative metamorphosis of the biopower: a person becomes a "product" of new drugs and genetically modified technologies, i.e., a "homunculus" in the engineering-biological dimension. There is less and less of its natural basis: the genotype changes, and, accordingly, immunity decreases, gender certainty, stress 
resistance degrades, etc. Changes in the genotype are a straight road to the growth of a person's dependence on the biological environment, with the only correction that this environment is continuously transformed. This cannot but cause concern, the result of which was the issue of the roundtable discussion "Science. Technologies. Man", the materials of which are published in "Philosophy of Science and Technology" journal. Particularly, V. A. Lektorsky emphasized that the transformation of a person caused by the influence of modern engineering and technology may take place in different ways. He said that it is possible to transform it with the help of NBIC technologies (nano-bio-informationcognitive - auth.), turning it into a "posthuman", i.e., in fact, killing it as a person. You can also realize that the development of culture, philosophy, art, literature, and science was the real transformation of a person. That is, the development of its value concepts, the creation of a new "human world". But this development went precisely along the path of humanizing the person and his relationships, and not on the path of his dehumanization, the real danger of which appears today [12]. This second vector of human development has to be provided and preserved in the scope of the modern transformation of biopower and biopolitics.

Secondly, it would be right to develop and prove the idea of biopower as the effect of human-acquired biogeocenoses on people's lives. Meanwhile, the power of existing biological systems lets us talk about the dependence of a person on his own biology, and through it - on biology as a whole. Finally, the birth of a child or the death of an old man is the result of a natural process, since no one "canceled" the total biopower. Due to the development of science, the biotechnologies of artificial conception are also focussed on the natural process of embryo development. No one has yet invented a way to create a person without the biological materials of his parents; no one has developed the "immortality syrum" (or the Macropoulos remedy in the famous short story by K. Chapek).

Meanwhile, since 1996 some genetically modified (GM) crops and related technologies have been marketed for quite a long time. In 2014, Kazakhstan shifted to the active development of GM crops. In 2019, the registration of new GMO lines was simplified to the limit in the United States. Over the past decade, even the European Food Safety Agency (EFSA) has progressively given favorable assessments and recommendations on the use of GM crops. In Russia, on June 24, 2016, the law prohibiting the cultivation and reproduction of genetically modified organisms (GMOs) and products was issued. However, the law enforcement practice once again appeared to be not up to par with the situation, and thus a wide range of GM products appeared on the shelves of Russian retail chains.

But in 2020, the Russian government released genetically modified soybeans and meal (animal feed) from registration. The policy of facilitating the import of genetically modified products into the Russian Federation and the development of GMO technologies at Russian enterprises is likely to be continued.

The situation with the COVID-2019 virus, the Ebola pandemic, avian influenza and some other diseases is a clear example of the transformation of biogeocenoses. At this point, we can only talk about the transformation of biopower as another demonstration of people's dependence on the biological environment and biological factors. Besides, this dependence often turns out to be not real, but virtual, contrived, appearing in the form of various phobias and complexes. Robotic systems are more and more often replacing physical labor, and neural networks are substituting intellectual labor [13]. This is also the case with biogeocenoses, in which natural traits are substituted (devalued) by artificial components. Therefore, it is required to create a new format for the development of bio -, agricultural and environmental policy, bioethics, development and improvement of biogeocenoses. We are talking about the creation of a biointellectosphere [14]. 
Thirdly, the biopower under current conditions is being converted. Yet, it fully preserves its manipulative character [15]. It is typical that in the scientific literature there is still an opinion that there is a negative and positive eugenics. In addition, ageism - age discrimination- is one of the negative aspects of this transformation. This term was first proposed by the American researcher R. N. Butler and was treated as discrimination against people based on age criteria [16]. Nowadays, there are various forms and directions of ageism [17, 18]. Its proponents account for this phenomenon by saying that in 2018, for the first time in history, the number of people aged 65 and older exceeded the number of children under the age of 5 . The number of people aged 80 and over is projected to triple, from 143 million in 2019 to 426 million in 2050.

However, this question is not so simple. On the one hand, with age, the activity of the processes of generating new ideas, extracting information from memory, etc. decreases. On the other hand, older people have a lot of life and occupational experience, and a lot of knowledge [19]. Thus, modern biopower has to avoid any age discrimination.

Fourthly, the above-mentioned negative manifestations of biopower transformation and existing biogeocenoses ask for a fundamental increase in the social responsibility of the authorities and producers in order to create a safe existence and prevent new threats and high risks. A way to solve this problem is to improve the system of secondary and higher education by developing and studying innovative courses in valeology, biomedicine, bioethics, anthropology, and cultural studies. These subjects have a high educational capacity and may be helpful in the formation of personal social and professional responsibility of future specialists, and especially in the development of creative abilities [20-21]. This is of paramount importance in the scope of managing the processes of transformation of modern biopower, the development of biogeocenoses, and the improvement of biopolitics.

\section{Conflict of interest}

Authors do not have any conflict of interest.

\section{Acknowledgement}

The work was made with the support of the Ural State Agrarian University.

\section{References}

1. E.N. Mishustin, Microorganisms as a component of biogeocenosis, 168 (Nauka, Moscow, 1984)

2. M. Fuko, Security, territory and population, 544 (Nauka, Saint Petersburg, 2011)

3. G. Agamben, Homo Sacer. Sovereign Power and Bare Life, 328 (Stanford University Press, Stanford, 1995)

4. K. Schmitt, Political theology, 336 (Kanon-press, Moscow, 2000)

5. L.M. Martseva, Labor in the Context of Russian Civilization: A Social and Philosophical Aspect, 311 (OMGUPS, Omsk, 2002)

6. Gene bank standards for plant genetic resources for food manufacturing and agriculture, FAO, Rome (2015)

7. A.F. Rafikova, Bul. of the Chel. St. Un 5, 60-66 (2010) 
8. D.Yu, N.G. Baryshnikov, L.A. Mizyurkina, Ec. Of. Reg, 13(2), 591-603 (2017)

9. Agroindustrial complex: particularities of state regulation. Analytical report. Agency for Political and Economic Communications, http://apecom.ru/projects/item.php?SECTION_ID=91\&ELEMENT_ID=5903

10. Yu. G. Chirkov, Chimera time. Big Gene Games, 397 (Akademkniga, Moscow, 2002)

11. Strategy of research and technological development of Russia, (2010) URL:http:// http://www.kremlin.ru/acts/bank/41449/page/1.

12. Ph. Of Sc. \& Tech, 20(2), 5-49 (2015)

13. V.V. Slyusarev, T.M. Khusyainov, Th. Ag. Of. Glob. St. of Mod. Glob. Proc, 4, 145$151(2018)$

14. S.V. Smirnov, Hist, phil, pol \& leg sc, cult and Art his. Qust. Of Th. \& Pr, 8, 196-199 (2016) ISSN 2618-9690

15. A.I. Zhelnon, Bul. Of Tom. St. Univ, 4, 49-56 (2018)

16. R.N. Butler, Th. Geron, 9(4), 243-246 (1969)

17. Yu. V. Astashova, Bul. Of South. Ur. St. Un, 12(1), 142-151 (2018)

18. V.N. Shakalova, Young. Sc, 4, 145-146 (2019)

19. A.A. Popel, Bul. Of Per, Nat. Res. Pol. Un, 3, 142-153 (2017)

20. A.Yu, Ob. Of Cul, 3, 251-262 (2019)

21. V.E. Beshlyk, A.G. Svetlakov, Agrarian Bulletin of the Urals, 9(163), 77-83 (2017) 